\title{
The Implementation of Inclusive Educational Policies in Elementary School
}

\author{
Winda Greatta Zakiah" ${ }^{*}$, Ravik Karsidi², Munawir Yusuf ${ }^{3}$ iD \\ 1,2,3 Department of Special Education, Postgraduate Program, Sebelas Maret University, Surakarta, Indonesia \\ *Corresponding author: windagreatta@yahoo.com
}

\begin{abstract}
The inclusive education policies were created for children with special needs based on the equality principle. The implementation of inclusive education policies in each region has a different level of success. This research aims to find out how the implementation of inclusive education policies in elementary schools of Surakarta was reviewed from Grindle's policy implementation theory. The method used in this research is a mixed-methods, which is involving 102 respondents and 9 informants from 12 inclusive schools. The data analysis used in this research was a descriptive statistic and interactive modeling analysis of Miles and Huberman. The results showed that the implementation of inclusive education policy had a positive impact on the students and their environment, with the level of implementation of inclusive education is $76.8 \%$, therefore the efforts are needed to optimize the implementation of inclusive education policies in the form of training for teachers and providing of supporting infrastructures.
\end{abstract}

Keywords: Policy Implementation, Inclusive Education, Elementary School

$\begin{array}{lll}\text { History: } & & \text { Publisher: Undiksha Press } \\ \text { Received } & : \text { 4 January } 2021 & \text { Licensed: This work is licensed under } \\ \text { Revised } & : 15 \text { February } 2021 & \text { a Creative Commons Attribution 3.0 License } \\ \text { Accepted } & : 16 \text { March } 2021 & \end{array}$

\section{Introduction}

Education is one of the most essential sectoral developments regarding the forming of human resources quality that affected the development of a country. On the other side, education is a basic right for every citizen regardless of social class, race, political choice, belief or physical and mental differences (Lie, 2020). In education Law Number 20 the year 2003 about National Education System Article 5 (1) it is explained that every citizen has the same rights to get a qualified education. Therefore, the government obliged to fulfilled the rights of every citizen to get qualified education, including providing access for children with special needs. The discussion of education quality in Indonesia, it cannot be denied that children with a special need have not got more attention moreover there is still a lack of facilities that do not accommodate the diversity (Hartadi, Dewantoro, \& Junaidi, 2019; Nisa, Mambela, \& Badiah, 2018). Nganji (2017) also stated that the current learning environment has not been designed properly to accommodate the needs of students with special needs.

The distribution of education for children with special needs is still an issue that is widely discussed in policy formulation forums and expert research (Amka, 2019; Lambrecht et al., 2020; Nurhadisah, 2019). Therefore, a smart solution is needed for children with special needs so they will get their rights and educational service needs (Efendi \& Malang, 2018). One of the government's efforts to expand opportunities and equal distribution of educational services for children with special needs is by organizing inclusive education 
programs provided through regular schools (Aas, 2019; Göransson, Lindqvist, Klang, Magnússon, \& Almqvist, 2019; Kenny, McCoy, \& Mihut, 2020; Savolainen, Malinen, \& Schwab, 2020). The concept of inclusive education is having the objective of involving children with disabilities in regular classes where teachers must use a variety of teaching approaches, work collaboratively and use various assessment methods (Lambrecht et al., 2020; Wardah, 2019). Through inclusive education, it is expected that it can eliminate discriminatory education and accommodate all of the needs of children with special needs in the scope of education. Inclusive education is also a means to provide a huge opportunity for children with special needs to get proper education according to their needs (Nurhadisah, 2019; Wardah, 2019). Stated that three dimensions reflect inclusive educational institutions, covering physical inclusion, curriculum inclusion and social inclusion (Booth \& Ainscow, 2002). Thus, the logical consequence that must be accepted by all implementers in educational institutions must accept students without exception, including students who experience physical, behavioural and psycho-social obstacles in regular schools that are attended by children without special needs (Ormrod, 2008).

Inclusive education policy in Indonesia has been running for more than 10 years, but based on data from the Directorate of Special Education Development in 2018 only $18 \%$ or about 299,000 of the 1.6 million children with special needs who have received inclusive education services. During that time, the success rate of inclusive education policy implementation in each region is different and still has many problems, one of which is in central Java. Haryono \& Sri (2016) view this issue from several aspects, covering: student management; the admission process that does not involve identification and assessment; curriculum management, which is indicated by lacking modification and individual learning provided; education staff management, which is indicated by the lack of understanding of teachers in implementing inclusive education programs; infrastructure management, which is indicated by the lack of infrastructure to support the learning process to students with special needs; financial management, which is indicated by the absence of a special financial budget for students with special needs; environmental management, which is indicated by the lack of social involvement. Based on these findings, it can be concluded that educational resources in inclusive schools are still low. The inclusive education program still needs reinforcement in the aspect of human resource capacity in the school that organizes Inclusive Education or (SPPI). Therefore, it is essential to collaborate with the implementers of education to get a better understanding of how to fulfill the needs of children with special needs in the scope of education, covering non-special education teachers, special education teachers, education staffs and administrative staffs.

During in the implementation of inclusive education policy in Indonesia, one of the cities in Central Java, Surakarta City, declared itself with the nickname 'Solo City of Inclusion' in 2013. The Mayor of Surakarta has enacted regulation Number 25-A year 2014 about the Implementation of Inclusive Education. But in its implementation in 2016 or 3 years after declaring itself as a city of inclusion, Yusuf, Choiri, \& Supratiwi (2017) found that Elementary schools in Indonesia, one they are in Surakarta, there is still found some problems related to the implementation of these policies such as less availability of the teachers and education staffs, teachers who do not have a special education background that affected to the lack of knowledge regarding the handling of children with special needs, as well as a disproportion between special companion teachers and inclusive schools and the time allocation. Based on the GPK data in 2018, the number of teachers for children with special needs is 122 teachers, while the number of children with special needs in the year 2019/2020 in the level of PAUD / TK (pre-school / kindergarten) to Junior High School Inclusion and special schools is estimated in the number of 1,623 ABK (Children with Special Needs). This number showed a significant comparison between the number of ABK 
and GPK (Children with Special Needs and Special Companion Teacher). Research related to the implementation of inclusive education has also been carried out by Amka (2019) in South Kalimantan where a similar problem has also appeared as a very dominant phenomenon faced in the implementation of inclusive education.

As a city that declares itself "City of Inclusion", the implementation of inclusive education policy in Surakarta, especially in primary schools, needs to be done to find out how the success rate of inclusive education policy organizers in the City that declares as a "City of Inclusion", whether there are still many problems such as other regions and whether previous problems are still encountered. Of course, ideally, Surakarta city becomes one of the national pilot areas in the implementation of inclusive education in accordance with Regulation of the Minister of National Education Number 70 of 2009 about inclusive education for students who have abnormalities and have the potential of intelligence and /or special talents. Implementation of inclusive education policy in Surakarta can be assessed the success rate by measuring or comparing the final result of the policy that has been implemented with the policy objectives. The implementation of inclusive education policy in Surakarta, especially in primary schools, can be assessed the success rate by measuring or comparing the final results of policies that have been implemented with policy objectives. Assessment of the successful implementation of inclusive education policy in Surakarta can be done in a variety of ways, one of which uses a top-down approach that can be interpreted as an approach that assesses the implementation of policies by mapping down to see the success or failure of policy implementation, among others by using the Merille S. Grindle policy implementation model. The policy implementation model by Grindle is a policy implementation model that explains that the assessment of policy implementation originates from the policy set, the program and the final result of the policy (Grindle, 1980; Leo, 2013).

In research related to inclusive education policy, researchers explained and described policy implementation not only based on variables derived from policymakers. Thus, this research was conducted to find out and describe how the success rate of inclusive education policy implementation in Surakarta elementary school was reviewed from the perspective of Grindle policy implementation theory after seven years the city declared as "City of Inclusion".

\section{Materials and Methods}

This research was combination research, a combination of qualitative and quantitative methods. This research was taken out of 102 respondents for questionnaire data filling as a quantitative data source and 9 informants for the interview as qualitative data for supporting data. Respondents and informants consisted of education council representative education, principals, special assistance teacher, classroom teacher, teacher subjects and parents from 12 inclusive elementary schools in Surakarta. The data collection technique used in this research was open-close-ended questions with four options, i.e. always, often, sometimes and never. Meanwhile, in the interview, the researcher used a semi-structured interview. Grindle's basic theoretical framework was used to arrange the interview indicators and guidance that adapt to National Educational Laws Number 70 the year 2019 about Inclusive Education for Students with special needs and special intelligence or special talents. The implementation of inclusive education based on the core of National Education Law is integrated with Grindle's theory are aspects of education staffs, the society supports, fund and infrastructure. Meanwhile, for the environment, the implementation is in the form of new students' admission, curriculum and learning process. The data analysis technique of quantitative data used descriptive statistics, meanwhile, the data analysis technique used of qualitative data was an interactive model from Miles \& Huberman. The validity and reliability test showed that instruments of 
research were fulfilled the criteria and proper to be used in the research as the counting result of the reliability questionnaire is 0.744 using the Alpha Cronbach technique.

\section{Results and Discussion Results}

The factual conditions regarding the implementation of inclusive education policies are reviewed based on Grindle's policy theory. Subarsono (2016) explained that the successful implementation of policies based on Grindle's implementation model is determined by two variables, covering the content of policy and context of implementation. The final results referred to the inclusive education policy are in the form of effects and changes experienced by the target group that is students with special needs. Based on research data that analyzed with objectives, which described the condition of the factual implementation of inclusive education policies of the elementary school in Surakarta was reviewed based on Grindle's theory of policy implementation to see the contents of the policy and context of implementation as indicators of to measure the success, showed that the level of the implemented policy of inclusive education in elementary schools of Surakarta is as follows:

Table 1. Summary on the implementation of inclusive education policy in Elementary School of Surakarta

\begin{tabular}{llccc}
\hline No. & \multicolumn{1}{c}{ Aspects } & $\begin{array}{c}\text { Total Ideal } \\
\text { Score }\end{array}$ & $\begin{array}{c}\text { Total Score of } \\
\text { Acquisition }\end{array}$ & $\begin{array}{c}\text { Level of } \\
\text { Implementation, \% }\end{array}$ \\
\hline 1. & Educational staff & 2448 & 1759 & 71.85 \\
2. & Society Support & 1632 & 1259 & 77.14 \\
3. & Financial & 1632 & 1156 & 70.83 \\
4. & Infrastructure & 3264 & 2393 & 73.31 \\
5. & Student Admission & 3672 & 3249 & 88.48 \\
6. & Curriculum & 2040 & 1618 & 79.31 \\
7. & Learning Process & 2448 & 1876 & 76.63 \\
\hline \multicolumn{7}{r}{ Average } \\
\hline
\end{tabular}

Content of policy

According to Grindle's theory, the content of policy refers to a review the how far the interests of the target group are contained in the content of the policy; the policies made are expected to contain the interests and benefits that will be experienced by the target group; the extent of the desired change of a policy; accuracy of a policy program; program implementer; and adequate resources (Leo, 2013). The interests and benefits of target groups are contained in Law Number 8 of 2016 about Persons with Disabilities. Article (10) states that persons with disabilities have the right to get qualified education at an inclusive and special education unit and are entitled to adequate accommodation as learners. The interest of the target group relates to students with special needs, as explained in National Educational Laws Number 70 of 2009 about Inclusive Education for Students with Disabilities and Potential Intelligence and/or Special Talents, in Article (2) it is clearly stated that education policy inclusive is an effort to fulfill the rights of students with special needs to be able to obtain educational services that are equal to other students. The interests of the target groups in the implementation of inclusive education are also contained in the laws and regulations in each region, one them is Surakarta has approved the Mayor Regulation Number 25-A of the year 2014 concerning the Implementation of Inclusive Education. Article (3) states the principles of implementing inclusive education needed by target groups, covering students with special 
needs, and then Article (4) explains the rights of students with special needs to participate in inclusive education. Based on several regulations, the interests and benefits of the target group, in this case, are students with special needs that have been covered in the contents of the policy.

A policy in detail specifies the implementer. Based on the finding of the research, implementer of inclusive education policies related to aspects of education staff with the acquisition of its implementation level is $71.85 \%$. It showed that about $71.85 \%$ of the capacity of the implementers implement inclusive education policies of elementary schools in Surakarta. In more detail, $45 \%$ of teachers often participate in activities to improve their understanding of students with special needs and only $8 \%$ of respondents answered that they are always able to handle students with special needs. As an effort to understand more about the students with special needs, the average respondent (49\%) often conducts activities seeking information about students with special needs. Meanwhile, there is $61 \%$ of respondents always monitor the abilities of students with special needs and $38 \%$ of respondents always do classroom management. From the aspect of the educational staff, most of the teachers participate in activities to improve understanding and often carry out activities seeking information about students with special needs. However, the ability to handle students with special needs is still in the low category.

An adequate resource is related to the aspects of social support, financial and infrastructure. The implementation of a policy must be supported by adequate resources to make the implementation is running well. Regarding the support of the resources, covering society support, the level of its implementation in the implementation of inclusive education policies is $77,14 \%$. Society support means human resources that support the maximum implementation of inclusive education policies. The results obtained $51 \%$ of respondents answered that there was the involvement of parents of students with special needs in activities at school. Furthermore, financial, the availability of adequate funds will facilitate the implementation of a program, in this case, the level of implementation is $70.83 \%$, with details $31 \%$ of schools making school budget plans and $29 \%$ of schools allocating funds for inclusive education every month. In the financial aspect, inclusive school education providers are all fulfilled. Regarding the infrastructure, the appropriateness level reached $73.31 \%$, with details there is $36 \%$ of respondents optimize an optimal infrastructure, $23 \%$ of respondents always planned procurement of infrastructure. However, only $27 \%$ provided instructional media facilities that adjusted the characteristics of students with special needs and only $28 \%$ of schools providing inclusive education had resource rooms (special classes). The aspects of infrastructure are still complained about with classrooms and school buildings that are not friendly to students with special needs.

The policy content variable reviews the appropriateness of a policy program that has been implemented. A policy program must be precise so that its implementation is in line with the expected goals. There is covering on precise on target, precise on needs and precise in use (Leo, 2013). The implementation of inclusive education policies, the basic foundation as a reference is National Educational Laws Number 70 of 2009 about Inclusive Education for Students with Disabilities and Potential Intelligence and/or Special Talents. According to the research, the average elementary school inclusive education providers have followed the reference has been set. However, not all aspects of the foundation base are the references are well realized. The content of the policy includes the benefits experienced by the target group and in its implementation, the policy is able to bring the expected changes. Organizers of inclusive education policies have the aim of providing quality education without any discriminatory character. All children can learn together and support each other (Lundqvist \& Bodin Ulrika, 2018; Wardah, 2019). Based on the findings of the research, inclusive education can increase the confidence of students with special needs and grow a sense of 
empathy and togetherness for other students and change the stigma of society towards peers and students with special needs.

\section{Context of Implementation}

This variable covers the implementation strategy, the responsiveness of the target group and the level of compliance of the target group. The scope of the implementation strategy in terms of National Educational Laws Number 70 of 2009 about Inclusive Education for Students with Disabilities and Potential Intelligence and/or Special Talents, which is the aspects of students' admission, curriculum aspect and learning aspect. Seen from the aspect of students' admission, the level of implementation is $88.48 \%$, which is the highest level of implementation of inclusive education policies among others. There is $86 \%$ of schools always admitting students with special needs and there $62 \%$ of schools plan to admit students with special needs. Seen from the aspect of the curriculum, the level of implementation is about $79.31 \%$ with details of $48 \%$ compiling special lesson plans and $40 \%$ of respondents who always coordinate with the Special Assistance in preparing special lesson plans. In modifying the curriculum, there is only $45 \%$ made modifications to the minimum score (KKM) and $49 \%$ modified the learning materials. Schools that provide inclusive education do not yet have a master curriculum so all plans and modifications are customized to school policies. At last, viewed from the learning aspect, the level of implementation is $76.63 \%$, with the detail there is $41 \%$ of respondents using media that match the characteristics of students, meanwhile, there is only $29 \%$ of teachers always discuss the subject matter with Special Assistance Teacher (GPK). There is also 45\% Special Assistance Teacher (GPK) who provided special assistance during the learning process.

The review on the level of responsiveness and compliance of target groups, they have an essential role because their behavior will determine the success of the policy. This research reviews the responsiveness and compliance of the target group viewed from the participation of students with special needs to participate in activities. Based on the finding of the research, there is $61 \%$ of students with special needs actively participate in activities at school. This is also supported based on the results of interviews with informants stating that students are always actively participating in activities in school. However, some of them have low participation because of the disability they have.

\section{Discussion}

Regarding the topic of research, this research gave attention to the implementation of inclusive education based on Grindle's implementation theory which analyzes aspects of contents of the policy and the environmental aspects, that concern the external conditions of policymakers and reviews the process of achieving the final result. The overall numbers that appeared in the finding of the research represent the level of achievement on the implementation of inclusive education at the elementary school level in Surakarta, showed the success of implementing the policy has already run well but still has not yet reached the maximum number.

Basically, the implementation of inclusive education policies that have been running was affected by implementers or human resources (Besic, Paleczek, \& Gasteiger-Klicpera, 2020). The implementers of the inclusive education policy consisting of school principals, classroom teachers, subject teachers, special companion teachers, and other education staff in schools that provide inclusive education. The majority of research findings around the world stated that there were still many teachers who do not understand and adapt to students with special needs (Elder \& Kuja, 2019; Schwab, Sharma, \& Hoffmann, 2019). A similar thing was also happening in the implementation of inclusive education in Elementary Schools in Surakarta, although overall the implementation of inclusive education could be categorized as 
good. In the fact, teachers as the most important factor in the learning process, need the optimal competence and understanding that affected the teaching and learning process in the classroom. The implementation of inclusive education in terms of the context implementation which includes the ability of implementers in implementing inclusive education policies in this study reached $71.85 \%$. Compared to the research findings from Yusuf et al. (2017) that number tends to be higher than the average number of human resource aspects of inclusion schools in Indonesia which is only $45.8 \%$.

In giving treatment to children with special needs, cooperation between Special Assistance Teachers and regular teachers is very important in order to build professional work and good relationships in developing learning strategies (Paulsrud \& Nilholm, 2020). The performance and competence of teachers in handling special situations in learning is very important (Moser Opitz et al., 2020; Semin, 2019; Wolomasi, Asaloei, \& Werang, 2019). Based on the finding of the research, in the Elementary school in Surakarta, the class teacher is rarely doing discussion with Special Teacher Assistance regarding the learning methods. In fact, some teachers still think that students with special needs are no different from other students so they get a task load and use the same assessment methods as other students, without any modification and adjustment to the characteristics and abilities of students with special needs. Meanwhile, the concept of inclusive education is aimed to involve children with disabilities in regular classes where teachers must use various teaching approaches, work collaboratively and use various assessment methods (Lambrecht et al., 2020; Wardah, 2019). This is due to the lack of knowledge of educators about children with special needs.

The teachers' professionalism in the implementation of inclusive education is considered as not optimal, because basically the professionalism of teachers in learning process can be determined by how the teachers create improvements and modifications to learning when facing situations that require educators to do so, such as dealing and facing students with special needs (Aas, 2019; Diahwati, Hariyono, \& Hanurawan, 2016; Wahyudi, Purnomo, \& Yoto, 2019). In line with the statement, Damayanti, Hamdan S., \& Khasanan (2017) said that the understanding of teachers in teaching and learning activities can affect students' learning achievements and have a positive and significant effect on student learning outcomes. The better the teachers' understanding of their students, the better the students will be able to receive the material given (Damayanti et al., 2017). Therefore, the conditions that are needed to be built in carrying out inclusive learning among teachers are awareness in dealing with special situations that require special development and modification, as well as cooperation built on the principle of work professionalism in dealing with students with special needs in terms of implementation in the learning process.

Reviewing the content aspects of the implementation of inclusive education policy in Surakarta Elementary School basically, the policy is influenced by adequate resources. Leo (2013) explained that adequate resources are related to community support, financial and infrastructure. Based on the finding of the research, the resources in schools that provide inclusive education are categorized as adequate, however many respondents have complained about the facilities and infrastructures. The lack of inclusive school facilities can be an obstacle in the learning process (Beyene \& Giannomuis, 2020; Yusuf et al., 2017). Meanwhile, in terms of community support, the results showed that parents of students with special needs participated actively in the implementation of activities at school. Unfortunately, only a few schools involved parents of students to attend special meetings to discuss the implementation of inclusive education, which is only $21 \%$ of the total school. Lie (2020), it is mentioned that basically in the formulation of inclusive education policies that are needed not only discussions carried out by professionals; stakeholders and implementers. In addition, it must also involve students with special needs and parents to reach a consensus that comes from the points of view, opinions and arguments regarding their special 
educational needs. Thus, there needs to be community support in the implementation of inclusive education policies.

The expected final result in inclusive education policy is the impact and changes experienced by the target group in accordance with the objectives set out in Regulation of the Minister of National Education Number 70 of 2009 about inclusive education for students who have abnormalities and have the potential of intelligence and /or special talents, namely, to realize the implementation of education that values diversity, and is not discriminatory. Based on the results of the study, the implementation of inclusive education policy in Surakarta elementary school has an impact on students and their environment. From the interview results obtained data that inclusive education has a positive impact on the personalities of other students where they can foster a sense of empathy and tolerance for diversity. Teachers who are not from special education backgrounds also experience the impact of inclusive education, their point of view towards students with special needs can change slowly, and they realize that there is the strength of students with special needs. The implementation of inclusive education policies in Elementary schools in Surakarta has been going well. Based on the results of interviews with 9 informants from representatives of the Surakarta' education council, two inclusive education teachers and six parents, it was explained that inclusive education also has an impact on the ability of children to be more focused in participating in learning, parents feel accommodated by the school. The feeling of insecurity about having children with special needs and their anxiety about the child's future gradually disappeared. Some research findings explained that many students and children with special needs experience low self-esteem (Khatib, 2012; Spain \& Blainey, 2017). However, the research findings show that inclusive education policies have an impact on students with special needs, one of them is increasing self-confidence, optimizing their potential and motivating them. As well as students with special needs can socialize with other students. Not only in the form of benefits obtained, the implementation of inclusive education policy also related to the changes obtained and community acceptance. Based on the results of data analysis, the inclusive education policy, there have been many changes in education. Inclusive education policy is a form of development of educational services for children with special needs with system changes in schools (Galaterou \& A., 2017; Savolainen et al., 2020; M. Schuelka, Engsig, \& Thyrring, 2020; M. J. Schuelka, 2018). People are starting to care about equality and education for children with special needs. This indicates that the quality of the implementation of inclusive education policies every year increases and can have a positive influence on children with special needs and discrimination against children with special needs will disappear for longer

\section{Conclusion}

The finding of the research showed that the implementation of the educational inclusive policy of the elementary school in Surakarta has a positive impact on both students and the environment. Viewed from Grindle's implementation policy theory that analyzed the content of policy and context of implementation, the real fact showed that the implementation of inclusive education leads to a positive impact on a person with a disability. On the other hand, there is still an obstacle in implementation in the form of lack of ability from nonspecial education teachers, curriculum issues, and lack of infrastructure for the learning process to students with special needs. Therefore, it is still needed efforts to optimize the implementation of inclusive education in the form of training for teachers with non-special education backgrounds and providing infrastructure to support the effective and efficient learning process for students with special needs. 


\section{References}

Aas, H. K. (2019). Teachers talk on student needs: exploring how teachers beliefs challenge inclusive education in Norwegian context. International Journal of Inclusive Education, 1-15. https://doi.org/10.1080/13603116.2019.1698065.

Amka. (2019). Pendidikan Inklusif Bagi Siswa Berkebutuhan Khusus di Kalimantan Selatan. Jurnal Pendidikan Dan Kebudayaan, 4(1), 86-101. https://doi.org/10.24832/jpnk.v4i1.1234.

Besic, E., Paleczek, L., \& Gasteiger-Klicpera, B. (2020). Don't forget about us: attitudes towards the inclusion of refugee children with(out) disabilities. International Journal of Inclusive Education, 24(2), 202-217. https://doi.org/10.1080/13603116.2018.1455113.

Beyene, W. M., \& Giannomuis, A. T. (2020). Inclusion, access, and accessibility of educational resources in higher education institutions: exploring the Ethiopian context. International Journal of Inclusive Education, 1-17. https://doi.org/10.1080/13603116.2020.1817580.

Booth, T., \& Ainscow, M. (2002). Index for Inclusion: Developing Learning a Participation in Schools. Centre for Studies on Inclusive Education (CSIE).

Damayanti, T., Hamdan S., \& Khasanan, A. (2017). Kompetensi Guru Dalam Proses Pembelajaran Inklusi Pada Guru SD Negeri Kota Bandung. Journal of Psychological Research, 3(1), 79-88. https://doi.org/10.29313/schema.v0i0.1947.

Diahwati, R., Hariyono, \& Hanurawan, F. (2016). Keterampilan Sosial Siswa Berkebutuhan Khusus di Sekolah Dasar Inklusi. Jurnal Pendidikan: Teori, Penelitian Dan Pengembangan, 1(8), 1612-1620. https://doi.org/10.17977/jp.v1i8.6682.

Efendi, M., \& Malang, U. (2018). The Implementation of Inclusive Education in Indonesia for Children with Special Needs: Expectation and Reality. Journal of ICSAR, 2(1), 142-147. https://doi.org/10.17977/um005v2i22018p142.

Elder, B. C., \& Kuja, B. (2019). Going to school for the first time: inclusion comittee members increasing the number of students with disabilities in primary schoosl in Kenya. International Journal of Inclusive Education, 23(3), 261-279. https://doi.org/10.1080/13603116.2018.1432082.

Galaterou, J., \& A., A. (2017). Teachers' Attitudes towards Inclusive Education: The Role of Job Stessors and Demographic Parameters. International Journal of Special Education, 32(4). Retrieved from https://eric.ed.gov/?id=EJ1184123.

Göransson, K., Lindqvist, G., Klang, N., Magnússon, G., \& Almqvist, L. (2019). Professionalism, governance and inclusive education - A total population of Swedish special needs educators. International Journal of Inclusive Education, 23(6), 559574. https://doi.org/10.1080/13603116.2018.1441339.

Grindle, M. S. (1980). Politics and Policy Implementation in the Third World. Princeton University Press.

Hartadi, D. R., Dewantoro, D. A., \& Junaidi, A. R. (2019). Kesiapan Sekolah dalam Melaksanakan Pendidikan Inklusif untuk Anak Berkebutuhan Khusus di Sekolah Dasar. Jurnal Ortopedagogia, 5(2), 90-95. Retrieved from http://journal2.um.ac.id/index.php/jo/article/view/9154.

Haryono, S., \& Sri. (2016). Evaluasi Pendidikan Inklusif bagi Anak Berkebutuhan Khusus (ABK) di Provinsi Jawa Tengah. Jurnal Penelitian Pendidikan, 32(2), 50-57. https://doi.org/10.15294/jpp.v32i2.5057.

Kenny, N., McCoy, S., \& Mihut, G. (2020). Special education reforms in Ireland: chaning 
systems, chaning school. International Journal of Inclusive Education. https://doi.org/10.1080/13603116.2020.1821447.

Khatib, S. A. (2012). Exploring the Relationship among Loneliness, Self-esteem, Selfefficacy and Gender in United Arab Emirates College Student. Europe's Journal of Psychology, 8(1), 159-181. https://doi.org/10.5964/ejop.v8i1.301.

Lambrecht, J., Lenkeit, J., Hartmann, A., Ehlert, A., Knigge, M., \& Spörer, N. (2020). The effect of school leadership on implementing inclusive education: How transformational and instructional leadership practices affect individualised education planning. International Journal of Inclusive Education, 1-15. https://doi.org/10.1080/13603116.2020.1752825.

Leo, P. (2013). Implementasi Program Pendidikan Non-Formal Untuk Narapidana Di Lembaga Pemasyarakatan Anak Kelas II A Kuotarjo. Universitas Negeri Yogyakarta.

Lie, J. H. (2020). Student participation in dialogue in individual subjetc curriculum meetings: students' and parents' perceptions. International Journal of Inclusive Education. https://doi.org/10.1080/13603116.2020.1749945.

Lundqvist, J., \& Bodin Ulrika, L. (2018). Inclusive Classroom Profile (ICP): a cultural validation and investigation of its perceived usefulness in the context of the Swedish preschool. International Journal of Inclusive Education, 25(3), 411-427. https://doi.org/10.1080/13603116.2018.1555867.

Moser Opitz, E., Schnepel, S., Krähenmann, H., Jandl, S., Felder, F., \& Dessemontet, R. S. (2020). The impact of special education resources and the general and the special education teacher's competence on pupil mathematical achievement gain in inclusive classrooms. International Journal of Inclusive Education, 27, 1-17. https://doi.org/10.1080/13603116.2020.1821451.

Nganji, J. T. (2017). Disability-aware adaptive and personalised learning for students with multiple disabilities. International Journal of Information and Learning Technology, 34(4), 307-321. https://doi.org/10.1108/IJILT-08-2016-0027.

Nisa, K., Mambela, S., \& Badiah, L. I. (2018). Karakteristik Dan Kebutuhan Anak Berkebutuhan Khusus. Jurnal Abadimas Adi Buana, 2(1), 33-40. https://doi.org/10.36456/abadimas.v2.i1.a1632.

Nurhadisah. (2019). Implementasi Pendidikan Inklusi dalam Pembelajaran Pendidikan Agama Islam. DAYAH: Journal of Islamic Education, 2(2), 201-211. https://doi.org/10.22373/jie.v2i2.4177.

Ormrod, J. E. (2008). Psikologi Pendidikan Jilid 1. Erlangga.

Paulsrud, D., \& Nilholm, C. (2020). Teaching for inclusion: a review of research on the cooperation between regular teachers and special educators in the work with students in need of special support. International Journal of Inclusive Education, 27, 1-15. https://doi.org/10.1080/13603116.2020.1846799.

Savolainen, H., Malinen, O.-P., \& Schwab, S. (2020). Teachers efficacy predicts teachers' attitudes towards inclusion - a longitudinal cross-lagged analysis. International Journal of Inclusive Education, 27, 1-15. https://doi.org/10.1080/13603116.2020.1752826.

Schuelka, M., Engsig, \& Thyrring, T. (2020). On the question of educational purpose: complex educational systems analysis for inclusion. International Journal of Inclusive Education, 27(6). https://doi.org/10.1080/13603116.2019.1698062.

Schuelka, M. J. (2018). Implementing Inclusive Education. University of Birmingham.

Schwab, S., Sharma, U., \& Hoffmann, L. (2019). How inclusive are the teaching practices of 
my German, Maths and English teachers? - psychometric propertiesof a newly developed scale to assess personalisation and differentiation in teaching practices. International of Inclusive Education, 26, 1-6. https://doi.org/10.1080/13603116.2019.1629121.

Semin, F. K. (2019). Competencies of Principals in Ensuring Sustainable Education: Teachers' Views. International Journal of Evaluation and Research in Education, 8(2), 201-212. Retrieved from https://eric.ed.gov/?id=EJ1220608.

Spain, D., \& Blainey, S. (2017). Enhancing Self-esteem in Adults with Autism Spectrum Disorder: a Pilot Cognitive Behaviour Therapy (CBT) Group Intervention. National Insitute for Health Research (NIHR), 3(2), 66-75. https://doi.org/10.1108/AIA-062016-0018.

Wahyudi, D. J., Purnomo, \& Yoto. (2019). Kompetensi Guru Keahlian Ganda Pasca Pelatihan On-In-On-In. Jurnal Pendidikan: Teori, Pelatihan Dan Pengembangan, 4(6), 821-827. https://doi.org/10.17977/jptpp.v4i6.12547.

Wardah, E. Y. (2019). Peranan Guru Pembimbing Khusus Lulusan Non-Pendidikan Luar Biasa (PLB) Terhadap Pelayanan Anak Berkebutuhan Khusus di Sekolah Inklusif Kabupaten Lumajang. Jurnal Pendidikan Inklusif, 2(2), 93-108.

Wolomasi, A. K., Asaloei, S. I., \& Werang, B. R. (2019). Job satisfaction and performance of elementary school teachers. International Journal of Evaluation and Research in Education (IJERE), 8(4), 575-580. https://doi.org/10.11591/ijere.v8i4.20264.

Yusuf, M., Choiri, S., \& Supratiwi, M. (2017). Evaluation of Inclusive Education Policies at the Level of Primary and Secondary Education in Indonesia. Jurnal Penelitian Dan Pengembangan Pendidikan Luar Biasa, 4(2), 147-154. https://doi.org/10.26740/inklusi.v2n2.p93-108. 